\title{
The Implementation of Flipped Classroom Learning on Management Accounting Course
}

\author{
Riwayadi ${ }^{1}$, Yulia Hendri Yeni ${ }^{2}$ \\ \{riwayadi@eb.unand.ac.id ${ }^{1}$,yuliayeni@yahoo.com.au² \\ 1,2 Faculty of Economics, Padang, Indonesia
}

\begin{abstract}
This research aims to evaluate the effectiveness of the implementation of Flipped Classroom Learning on Management Accounting Course in achieving the course's expected learning outcomes compared to traditional learning. The research type is applied research. The population is the students who are taking management accounting courses This research uses census sampling. It is found that flipped learning increases the material understanding of students as indicated by the increase of formative assessment results using Kahoot. Flipped learning also increases the final grade. This research also found that flipped learning (1) can help the students to have better conceptual (2) can encourage the students to do self-learning and collaborative learning, and (3) can provide the learning flexibility. Students have also benefited from online learning videos and recommended keeping on the flipped classroom learning.
\end{abstract}

Keywords: Flipped Classroom, Traditional Learning, Course's Expected Learning Outcomes.

\section{Introduction}

Management accounting is a compulsory course offered in the $4^{\text {th }}$ semester. This course currently uses the traditional classroom model. In the traditional classroom, students have no (or little) knowledge about the subject when they come to class. In class, they get taught all the knowledge, and it's often the basic knowledge about a subject. Students have to do the more comprehensive knowledge at home, it's called homework. The process of thoughts is mostly viewed after doing a test. Students don't have direct access to the knowledge. The teacher stands between the students and the knowledge. Students who attend a traditional education mostly have to do homework after contact moments. The flipped classroom is effective to improve the student creativity, responsibility, and learning skills [1].

Using the traditional classroom, the total number of management accounting students who got grade B- and below are 25\%. This significant percentage should be improved since the job markets require the minimum cumulative GPA of 3 ( 4 for the highest). To improve the student grade, the flipped classroom is proposed to be developed and implemented.

Problem definition can be formulated as follows: is the flipped classroom learning more effective to achieve management accounting course's expected learning outcomes (CELOs) compared to traditional classroom learning?

The research objective is to evaluate the effectiveness of the flipped classroom learning in achieving management accounting course's expected learning outcomes. The research benefit 
is to provide the input for undergraduate accounting study program and lecturers in developing the effective learning model to achieve management accounting course's expected learning outcomes.

\section{Research Method}

This research is applied research that emphasizes practical problem solving directed to answer the specific questions for the purpose of policy development, action, or particular performance [3]. This research is the evaluation research that is used for the evaluation of the effectiveness of an action, activity, or program [3]. This research is a qualitative approach that uses data in the form of sentences written or verbal, behavioral, phenomena, events, knowledge, or the object of the research [4]. Qualitative research is concerned with developing the explanation of social phenomena. It aims to help us to understand the world in which we live and why things are the way they are [2].

The subject of this research is Andalas University's accounting students who take management accounting course. The population is III/Int-A Class's international program accounting students and III/A2 Class's regular program accounting students who took the management accounting course in the second semester of 2018/2019. The research uses census data, that is, all III/Int-A Class's international program accounting students and all III/A2 Class's regular program accounting students who took the management accounting course. There are 61 students of III/Int-A Class's international program and III/A2 Class's regular program who took the management accounting course in the second semester of 2018/2019. The research was conducted in the semester of 2017/2018 for 6 months (January June 2019).

The research uses primary data which are gathered by questionnaire and observation. Data are collected using two methods: observation and survey. Observation is conducted when the students are taking Kahoot's quiz. The observation aims to assess the student enjoyable of Kahoot's quiz formative assessment. The survey is conducted by distributing the questionnaire to the students on the final exam schedule. Questionnaire is developed using 5 likert scales: 1 (highly agree), 2 (agree), 3 (neutral), 4 (not agree) and 5 (highly not agree).

The steps of data analysis are: (1) tabulating the questionnaire, (2) calculating the average score of each question by dividing total score with the total number of respondents, and (3) drawing the conclusion. Besides the questionnaire, the effectiveness of the learning method is also assessed by looking at the final grade and Kahoot's quiz grade before and after the implementation of flipped classroom learning

\section{Results and Conclusion}

\section{Formative Assessment Results}

The formative assessment results using flipped classroom learning are presented in Table 3.1. below. 
Table 1. The Formative Assessment results using Flipped Learning

\begin{tabular}{lll}
\hline No. & Topic & Kahoot's Score \\
\hline 1. & Introduction to Management Accounting & $73,24 \%$ \\
2. & Cost Concepts & $75,07 \%$ \\
3. & Standard Costing & $66,51 \%$ \\
4. & Variable Costing & $58,05 \%$ \\
5. & CVP Analysis - Single Product Setting & $64,71 \%$ \\
\hline & Average & $67,52 \%$ \\
\hline
\end{tabular}

The formative assessment results using full face to face learning (traditional classroom) are presented in Table 3.2. below.

Table 2. The Formative Assessment results using Full Face to Face Learning

\begin{tabular}{lll}
\hline No. & Topic & Kahoot's Score \\
\hline 1. & CVP Analysis - Multiproduct Setting & $59,85 \%$ \\
2. & Tactical Decision Making & $66,60 \%$ \\
3. & Functional-Based Responsibility Accounting & $58,52 \%$ \\
4. & Transfer Pricing & $76,28 \%$ \\
\hline & Average & $65,31 \%$ \\
\hline
\end{tabular}

Table 3.1 dan 3.2 above shows that the average score of the formative assessment using flipped classroom learning was $67,52 \%$ which is higher than the average score of the formative assessment using full face to face learning 65,31\%. It means that by using flipped learning, 67,52\% of total students who took Kahoot's quiz had the correct answer while by using face to face learning, only $65,31 \%$ of total students who took Kahoot's quiz had the correct answer. Based on this fact, there is evidence that flipped classroom learning can improve the student's understanding of learning materials compared to full face to face learning.

\section{Final Grade}

The student achievement of flipped classroom learning implementation can also be seen in their final grade. The students who have more understanding of learning materials will also increase their final grades. It can be seen by comparing the final grade before and after the implementation of flipped classroom learning. The comparison of the student final grade before and after the implementation of flipped classroom learning is presented in Table 3.3 below.

Table 3 Comparison of the Student Final Grade Before and After the Implementation of Flipped Classroom Learning

\begin{tabular}{lll}
\hline & Before Flipped Learning & After Flipped Learning \\
\hline A & $15 \%$ & $25 \%$ \\
A- & $26 \%$ & $13 \%$ \\
B & $24 \%$ & $23 \%$ \\
B & $10 \%$ & $25 \%$ \\
B- & $13 \%$ & $13 \%$ \\
C + & $7 \%$ & $1 \%$ \\
C & $5 \%$ & $0 \%$ \\
\hline Total & $100 \%$ & $100 \%$ \\
\hline
\end{tabular}


Based on Table 3,3 above, it is found that the number of students who got grade A increase from $15 \%$ (before the implementation of flipped classroom learning) to $25 \%$ (after the implementation of flipped classroom learning). There is shifting from grade A- to A. In the same case, the number of students who got grade B and B+ also increase from $34 \%$ (before the implementation of flipped classroom learning) to $48 \%$ (after the implementation of flipped classroom learning. So, there is evidence that flipped classroom learning can improve the student's understanding of learning materials compared to full face to face learning.

\section{Questionnaire Results}

Of 61 questionnaires distributed to the respondents, 58 questionnaires are returned (95\%). The results are summarized in Table 3.4 below.

The questionnaire results show that the students give scores for all questions above 4 with an average score of 4,33. Questionnaire results show that flipped classroom learning is highly recommended to be implemented on management accounting course because:

1) Can help the students to have a better understanding of management accounting concepts

2) Can encourage the students to do self-learning and collaborative learning

3) Can provide the flexibility of students to learn anytime and anywhere

4) Can make the teaching and learning process to be more interesting for the students

Students recommend that the online learning video of management accounting should keep it on.

Table 3.4. Questionnaire Result.

\begin{tabular}{|c|c|c|c|}
\hline NO. & PERTANYAAN & Nilai & Rata2 \\
\hline \multicolumn{4}{|c|}{ Pemahaman Konsep } \\
\hline 1 & $\begin{array}{l}\text { Pembelajaran akuntansi manajemen dengan video online (dalam jaringan } \\
\text { / Daring) memudahkan saya memahami konsep akuntansi manajeman } \\
\text { dibandingkan pembelajaran tatap muka }\end{array}$ & 4,19 & \\
\hline \multicolumn{4}{|c|}{ Motivasi Belajar } \\
\hline 2 & $\begin{array}{l}\text { Pembelajaran akuntansi manajemen dengan video online memotivasi saya } \\
\text { untuk belajar mandiri dan atau kelompok }\end{array}$ & 4,24 & \\
\hline 3 & $\begin{array}{l}\text { Pembelajaran akuntansi manajemen dengan video online memudahkan } \\
\text { saya dalam mengerjakan tugas kelompok yang diberikan }\end{array}$ & 4,29 & 4,19 \\
\hline \multicolumn{4}{|c|}{ Fleksibilitas Belajar } \\
\hline 4 & $\begin{array}{l}\text { Pembelajaran akuntansi manajemen dengan video online memberikan } \\
\text { keleluasaan bagi saya untuk mempelajari kapan saja dan dimana saja }\end{array}$ & 4,60 & \\
\hline \multicolumn{4}{|c|}{ Kesenangan penilaian formatif } \\
\hline 5 & $\begin{array}{l}\text { Penilaian (assessment) pembelajaran akuntansi manajemen dengan video } \\
\text { online dengan menggunakan kuiz kahoot online learning game sangat } \\
\text { menarik dan menyenangkan }\end{array}$ & 4,50 & \\
\hline 6. & $\begin{array}{l}\text { Hasil kuiz kahoot secara real time menjadi umpan balik (feedback) yang } \\
\text { sangat berharga bagi saya untuk memperbaiki kekurangan dalam belajar }\end{array}$ & 4,31 & \\
\hline 7. & $\begin{array}{l}\text { Kuiz kahoot mendorong saya untuk mempelajari video online akuntansi } \\
\text { manajemen secara lebih baik agar bisa meraih skor tinggi }\end{array}$ & 4,52 & 4,44 \\
\hline \multicolumn{4}{|c|}{ Keberlanjutan } \\
\hline 8 & Saya merasakan manfaat belajar video online akuntansi manajemen & 4,40 & \\
\hline 9 & $\begin{array}{l}\text { Saya sangat menyarankan video pembelajaran online akuntansi } \\
\text { manajemen diterapkan untuk seterusya }\end{array}$ & 4,52 & 4,46 \\
\hline & Rata-rata & 4,33 & \\
\hline
\end{tabular}




\section{References}

[1] Damayanti, Herry Novis dan Sutana, Efektivitas Flipped Classroom Terhadap Sikap dan Ketrampilan Belajar Matematika di SMK, Jurnal Manajemen Pendidikan, Vol 11, No. 2, Januari 2016: $2-8$

[2] Hancock, Beverley. 2002. An Introduction to Qualitative Research. Trent Focus Group. University of Nottingham

[3] Indriantoro, Nur dan Supomo, Bambang (1999), Metodologi Penelitian Bisnis Untuk Akuntansi dan Manajemen, Edisi Pertama, Yogyakarta: BPFE

[4] Moleong, Lexy J., (2006), Metode Penelitian Kualitatif, Edisi Revisi, Bandung: Remaja Rosdakarya 